\title{
Investigation of simultaneous of CADM1 gene methylation pattern and HPV virus quantification as a diagnostic biomarker in Cervical Cancer
}

\author{
Asma Soltanalizadeh $^{1}\left(\underline{D}\right.$, Changiz Ahmadizadeh ${ }^{2}$ \\ ${ }^{1}$ Department of microbiology, Ahar Branch, Islamic Azad University, Ahar, Iran. \\ ${ }^{2}$ Corresponding author; Department of microbiology, Ahar Branch, Islamic Azad University, Ahar, Iran. \\ Tel: +989104030464 \\ Email:dr_ahmadizadeh@yahoo.com
}

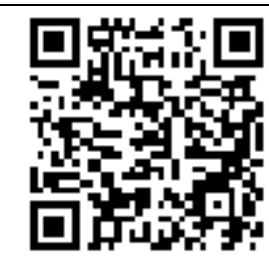

Citation Soltanalizadeh A, Ahmadizadeh Ch. [ Investigation of simultaneous of CADM1 gene methylation pattern and HPV virus quantification as a diagnostic biomarker in Cervical Cancer]. J Birjand Univ Med Sci. 2020; 27(1): 44-55. [Persian]

DOI http://doi.org/10.32592/JBirjandUnivMedSci.2020.27.1.103

Received: July 4, 2019

Accepted: November 4, 2019

\begin{abstract}
Background and Aim: Researches have shown that promoter methylation of the CADM1 gene is one of the main mechanisms is to silence its expression in cancer cells. The objective of this study was to determine the methylation pattern of the CADM1 gene promoter and to quantify the human papillomavirus.

Materials and Methods: In this research, 75 tumor tissues and 75 tumor marginal tissue samples taken from patients with definitive diagnosis of cervical cancer were examined. After extraction of DNA and ensuring the quality and quantity of DNA extracted by spectrophotometry and the agarose gel electrophoresis method, the methylation pattern of the CADM1was performed by the HRM method. Determining the methylation pattern of the CADM1 gene, without considering the type of involved variants was performed by using the Eva Green method and comparing the high-resolution melting point and HPV quantities were determined after isolation from the block.

Results: Methylation of CADM1 gene in cervical tumor cells increased significantly $(\mathrm{P}<0.0001)$ in comparison with the tumor margin before and after radiotherapy. But the change in the level of methylation of tumor cells before and after radiotherapy was not significant. This means that radiotherapy does not affect the level of methylation of the CADM1 gene. Moreover, the level of methylation of CADM1 gene in patients with HPV titer higher than $500 \mathrm{ml} / \mathrm{IU}$ was significantly more than that of patients with HPV titer lower than $500 \mathrm{ml} / \mathrm{IU}$.
\end{abstract}

Conclusion: Use of DNA methylated of the cancer cells as a prognosis for cervical cancer in HPV positive women it's appropriate, also the CADM1 gene can be used as a marker of cervical cancer.

Key Words: Cervical Cancer; HPV Virus; Methylation 


\title{
بررسى همز مان الكوى متيلاسيون زن CADM1 و كميت ويروس HPV به عنوان نشانغر زيستى تشخيصى در سرطان سرويكس
}

\author{
اسماء سلطانعلىزاده' (DiD)، جنكيز احمدىزاده
}

جִكيله

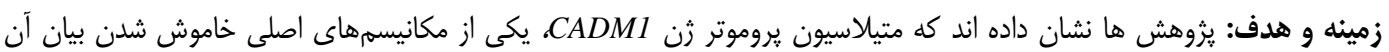

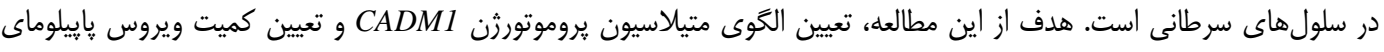
انسانى بود.

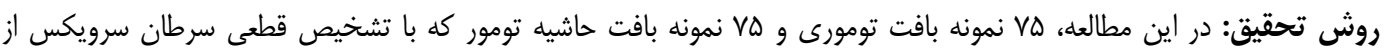

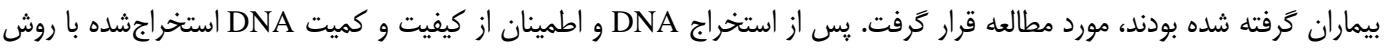

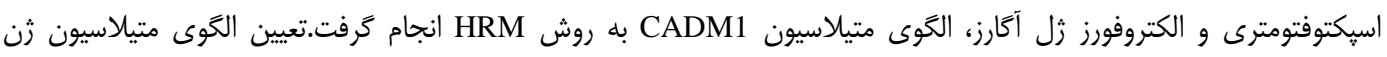
CADM1

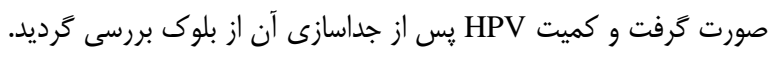

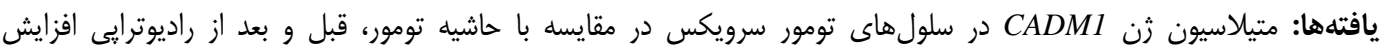

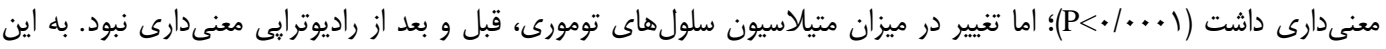

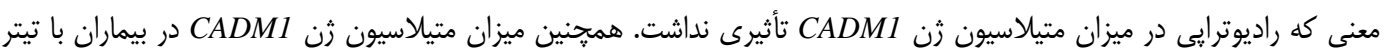

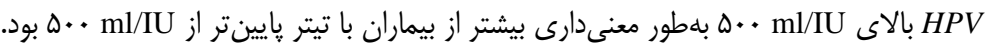

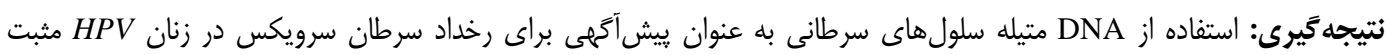

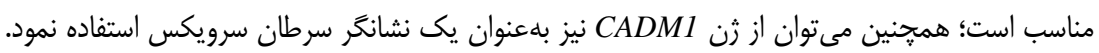
وازههاى كليدى: سرطان سرويكس؛ ويروس باييلوماى انسانى؛ متيلاسيون

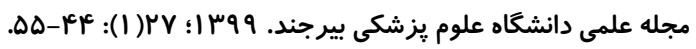

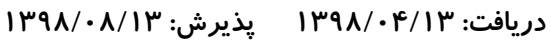




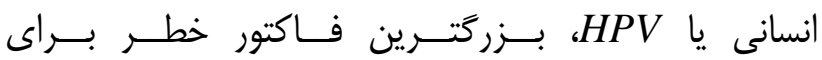

مقدمه

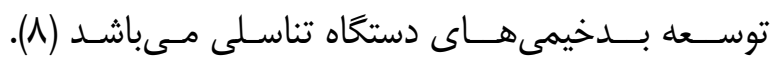

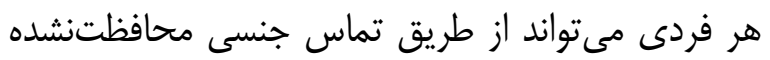

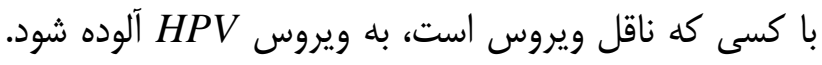
انواع مختلفى از ويروس HPV وجود دارد كه نقش متفاوتى

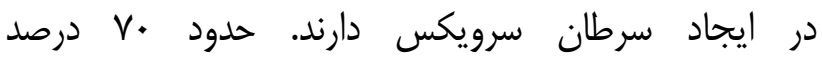
بيويسىهاى سرطان دهانه رحهم، حاوى عفونت پإييلومايى از

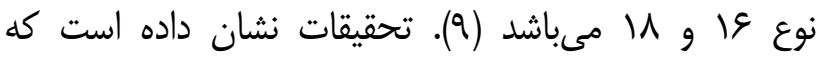

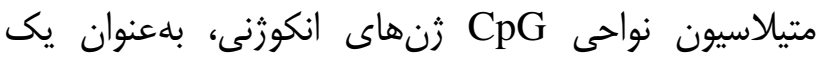

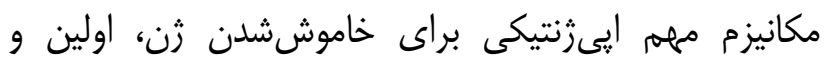

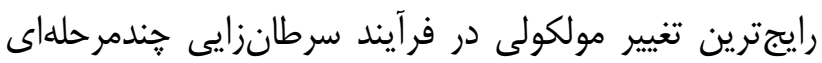

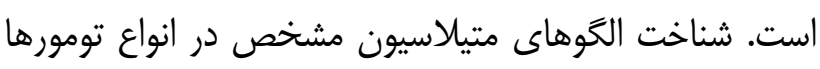

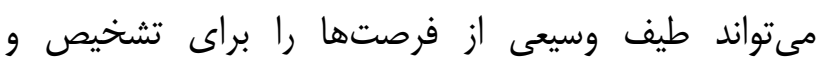

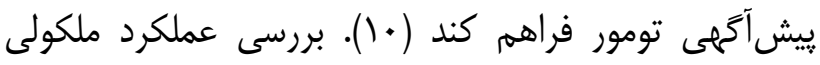

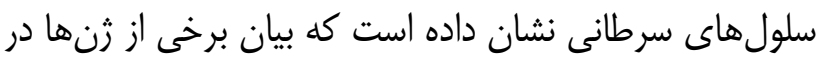

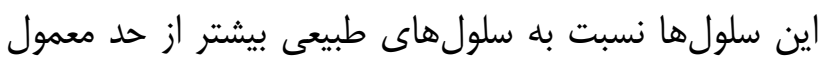

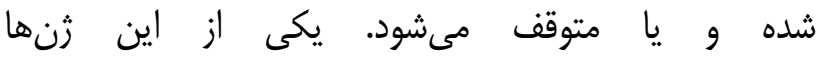

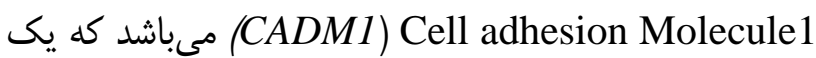

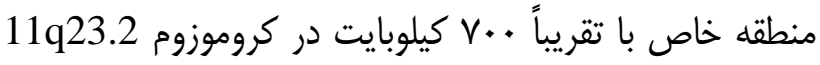

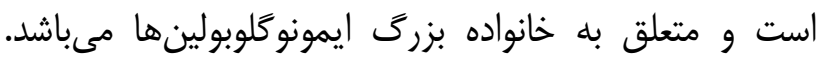

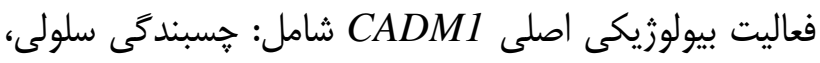

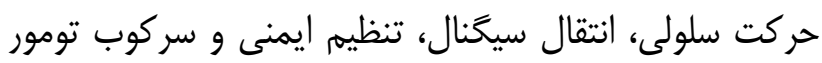

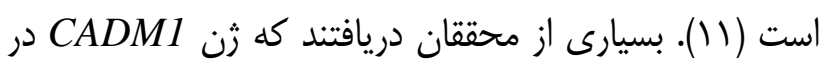

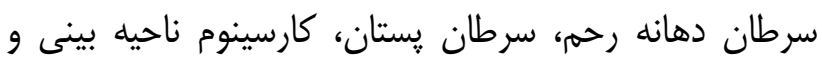

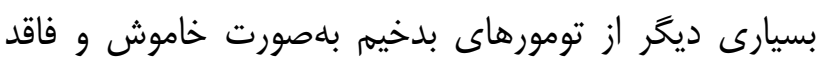

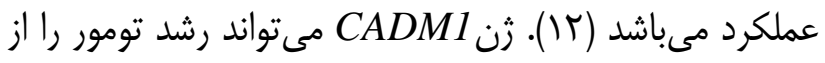
Proliferative and Propoptotic طريق فعاليتهاى سوق دهد و از دست رفتن بيان آن مىتواند منجر بان بان تهاجم

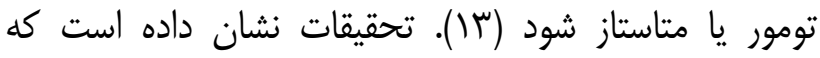

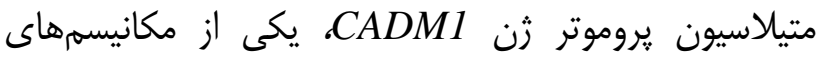

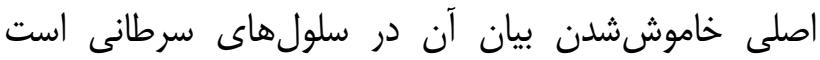

سرطان دهانه رحم، دومين سرطان شايع در ميان زنان

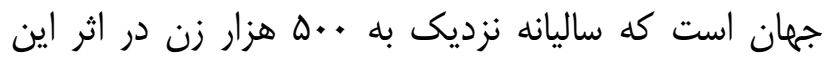

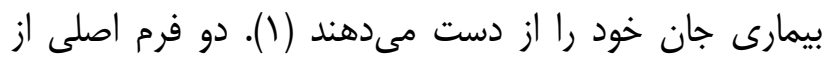

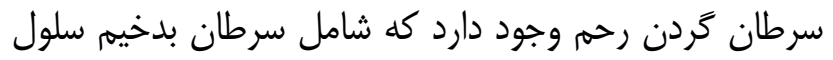
سنكفرشى (Squamous cell carcinomas) آدنوكارسينوماى كردن رحم (Adenocarcinomas) مى باشد.

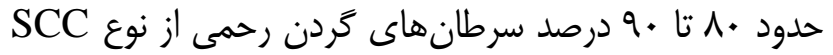

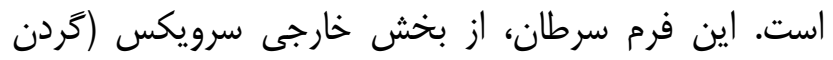

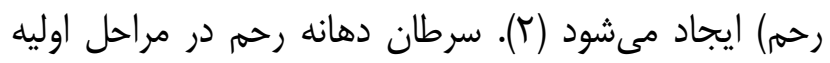

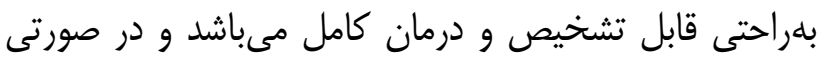

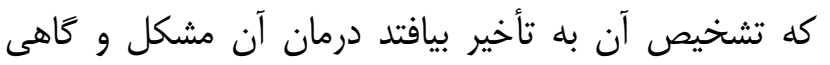
ناموفق خواهد بود (ب). تشخيص زودهنكام اين سرطان

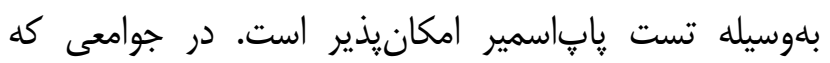

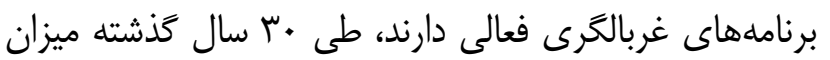

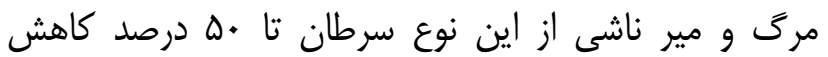
يافته است (ז). براساس مطالعات انجامشده، در كشور سوئد هو درصد زنان نسبت به برنامههاى غربالكرى سرطان إنان دهانه رحم آكاهى داشته و حداقل يكبار براى انجام اين تست ندان مر اجعه نمودهاند (ه). يكى از دلايل اصلى سرطان يا بهعبارتى، دليـل اوليه

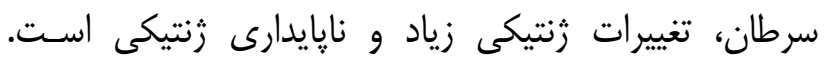

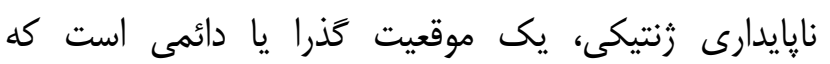

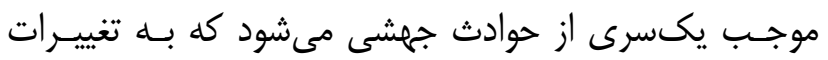

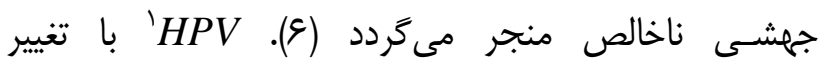
يروتوانكوزن و ثنهاى تومور سايرسور، باعـث ايجـاد

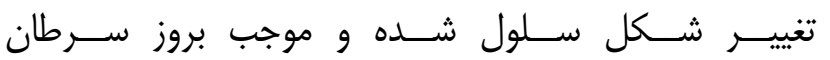
مىشود. انكوزنها از موتاسيون بروتوانكوزنها و يا يا از بيان

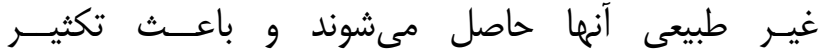

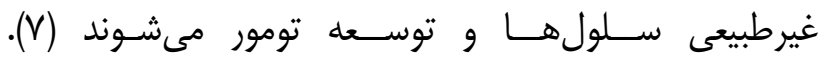

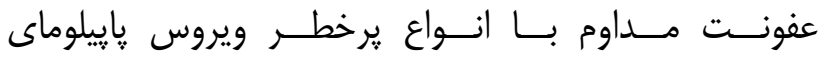

${ }^{1}$ Human papillomavirus 
انتقال داده شد و بهمدت يك دقيقه در دماى اتاق

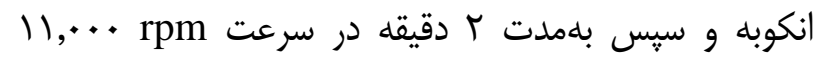
سانتريفيوز شد؛ فيلتر و RTA Receiver دور انداخته شد و و مجدد مخلوط به داخل RTA Spin Filter داخل RTA ماتل

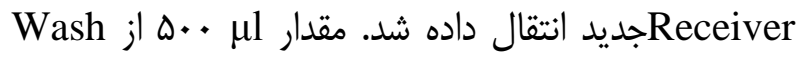
Buffer I

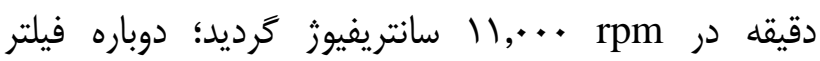
و RTA Receiver دور انداخته شد و مجدد مخلوط به داخل دورئل داخل Receiver RTA Spin Filter

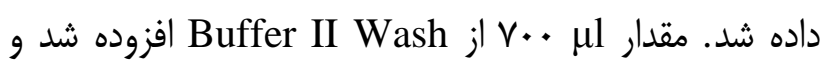

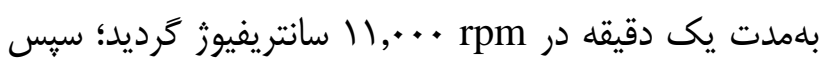

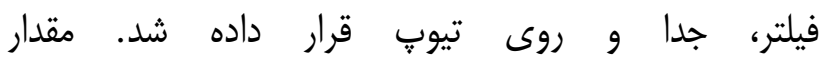

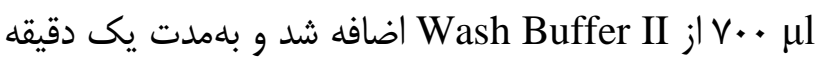
در سرعت 11, +. rpm سانتريفيوز انجام گرفت. فيلتر و Filter RTA Spin دور انداخته و Receiver Tube RTA داخل تيوپ جديدى انتقال داده شد و بلمدات عأ دقيقه براى حذف كامل اتانول، در حداكثر سرعت سانتريفيوز شد. فيلتر

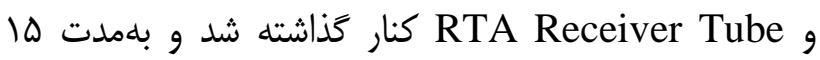
دقيقه داخل فيلتر جديدى انتقال داده شد. مقدار Elution Buffer RTA Spin Filter

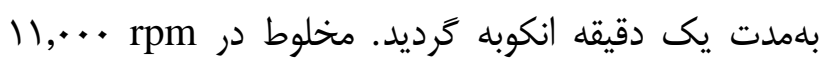

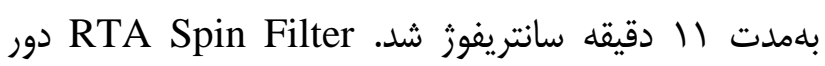
انداخته شد و در تيوب هات ال ميلى ليترى بسته و و

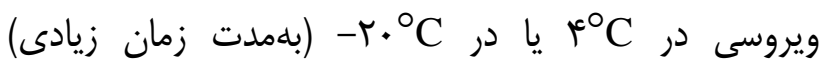
ذخيرهسازى شد.

\section{بررسى متيلاسيون زن CADM1:}

ابتدا براى اين بررسى، تغييرات متيلاسيون بر رون رون

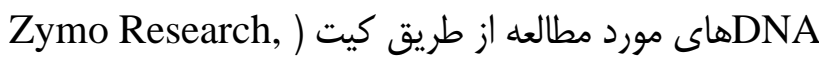
EZ-96 DNA Methylation-Gold ${ }^{\mathrm{TM}}$ (Irvine, CA طبق دستور العمل شركت سازنده آن مورد مطالعه قرار گرفت.
با توجه به اهميت يافتن نشانگر هاى زيستى تخصصى

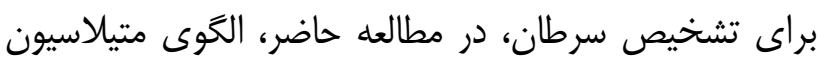

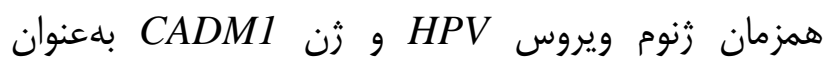

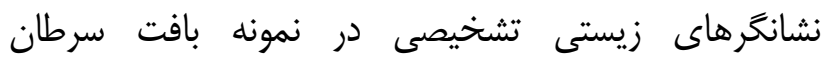
سرويكس، مورد بررسى قرار گرفت. اين مطالعه از نوع مورد- شاهدى مىباشد كه داراى كد اخلاق به شناسه مصوبه كميته اخلاق دانشگاه آزاد اسلامى واحد تبريز است.

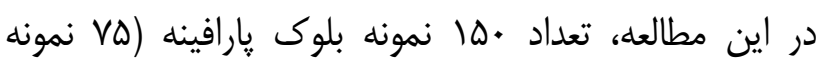
بافت سرطانى و VD نمونه بافت مارزينال) سرويكس مورد نمانه

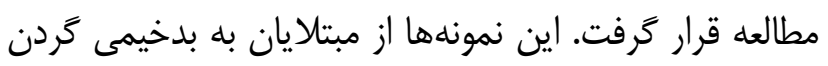

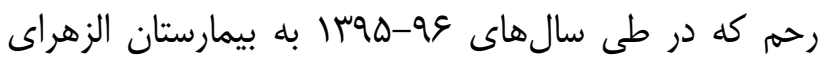

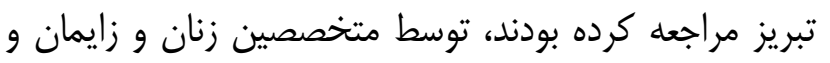
ياتولوزيست جمعآورى شدند. قبل از جمعآورى نمونه، از كليه بيماران رضايتنامه كتبى دريافت شد.

\section{مراحل استخراج DNA:}

توتال از بلوى يارافينه دريافتى طبق دستورالعمل

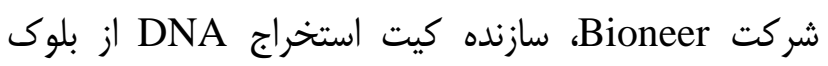

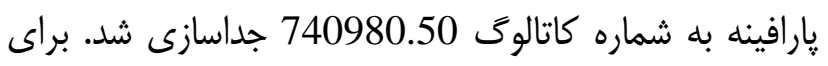

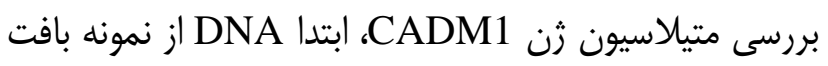

$$
\text { سرويكس بلهورت زير جداسازى گرديد: }
$$

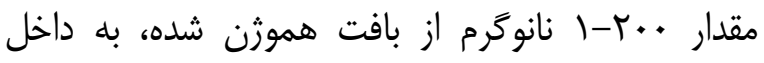

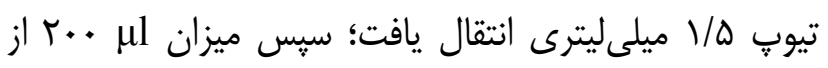
Lysis Buffer HL كامل مخلوط شد و بdمدت ه دقيقه در دماى اتاق در حالت r continuously shaking

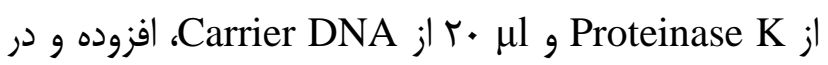
داخل ورتكس مخلوط شد.

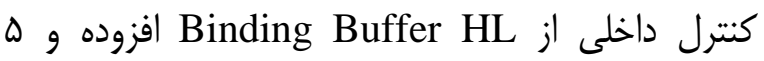
RTA Spin سرى با يايتيخ مخلوط شد. مخلوط به داخل آنس 
نرمافزر 2000/3000/6000، همه ه استاندارد در منو ويرايش نرمافزار TMotorGene تعريف شدند. استانداردها بهصورت

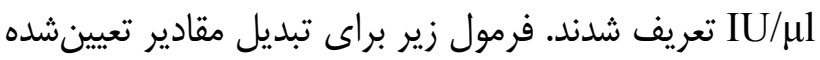

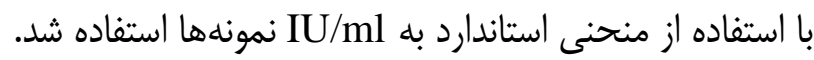
$\operatorname{Result}(\mathbf{I U} / \mathrm{ml})=\frac{\operatorname{Result}\left(\frac{\mathrm{IU}}{\mu \mathrm{l}}\right) \times \text { Elution Volume }(\mu \mathrm{l})}{\text { Sample Volume }(\mathrm{ml})}$

تعيين حجم نمونه با استفاده از فرمول زير و با در نظر

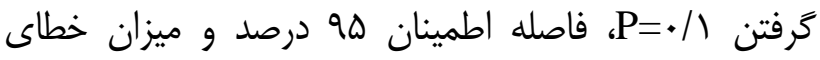

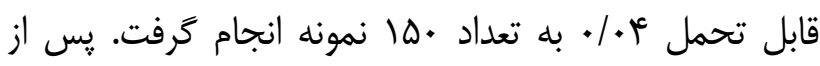

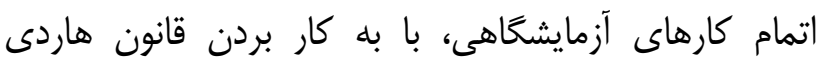

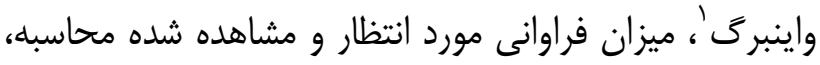

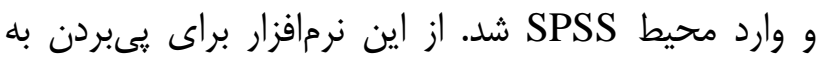

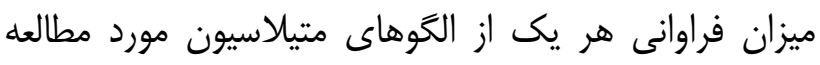

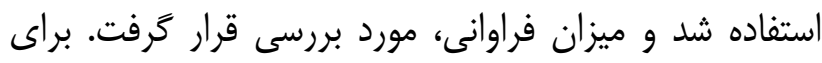

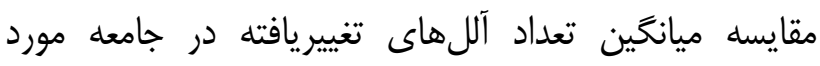

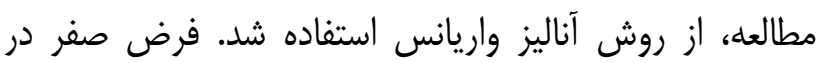
آناليز واريانس، برابر بودن ميانكَين متغير وابسته در تمام آنام

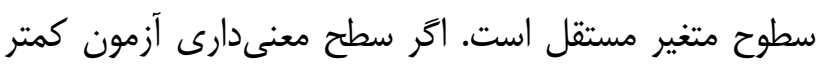

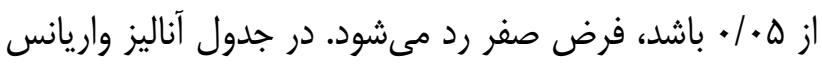

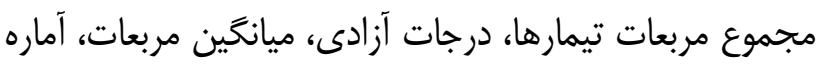
F و سطح معنى دارى آناليز واريانس محاسبه شد. شئ.

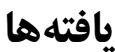

\section{آناليز كيفى SNA}

بلمنظور تأبيد كيفى DNA استخراجى، الكتروفورز

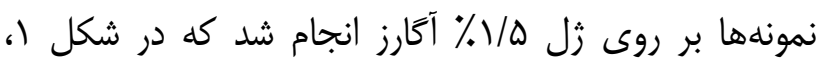

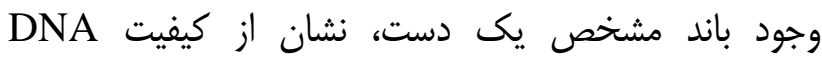
استخر اجى دارد.

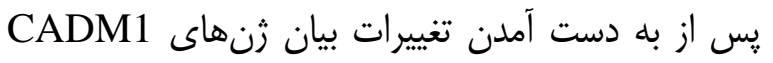
در تمامى موارد مورد مطالعه، بيماران به دو كروه تقسيم شدند

\footnotetext{
${ }^{1}$ Hardy-Weinberg principle
}

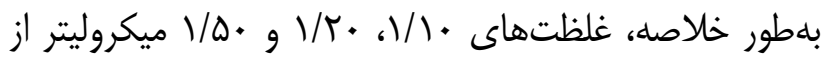

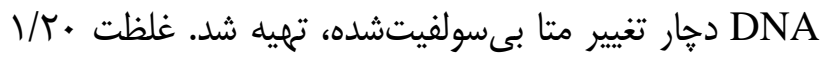

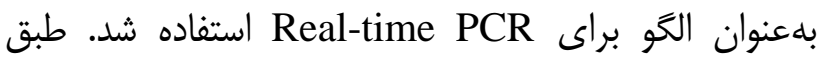
دستورالعمل كيت، واكنش تكثيرى در حجم •r ميكروليتر

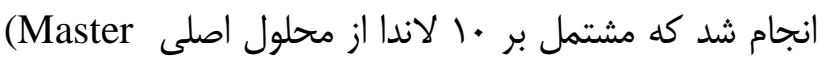

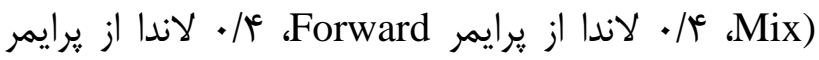

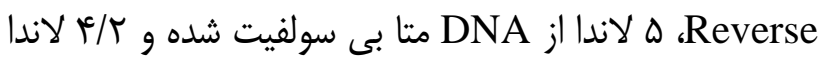

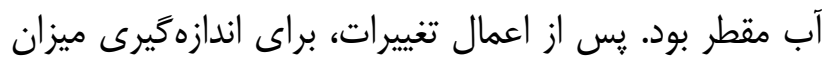

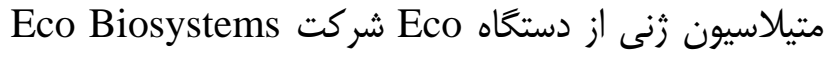

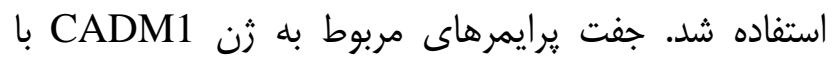
استفاده از نرمافزار Primer 3 طراحى و توسط شرك كت بايوني

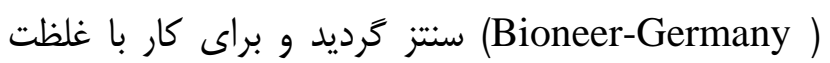

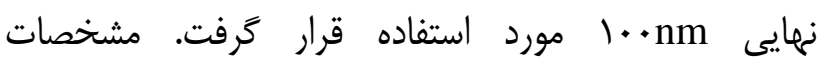
آغازَّرهاى استفادهشه در اين مطالعه بهصورت زير مىباشد:

Forvard primer: 5'-GACTCTACGGCTGCCTTCTC-3', Reverse primer: 5'-AGAAGTGCATGCGTGCTTTG-3'.

واكنش تكثيرى براى •f سيكل بر طبق الخوى دمايى زير انجام شد: - ماكي

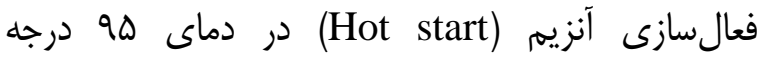
سانتى كراد انجام شد؛ دناتوراسيون اوليه و Holding در دماى داى دائ

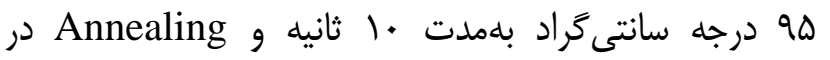

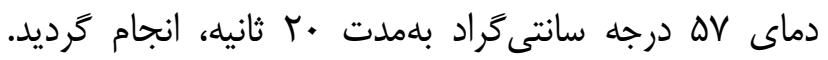
طويلسازى در دماى كV V درجه سانتى

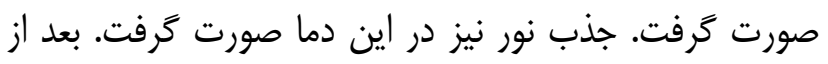

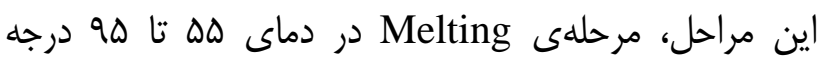

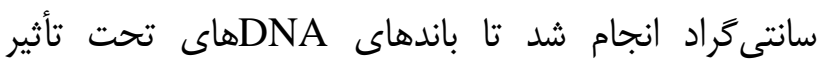

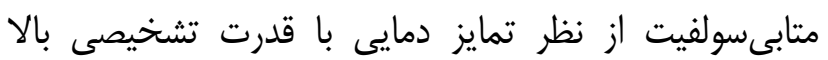
تفكيك شوند.

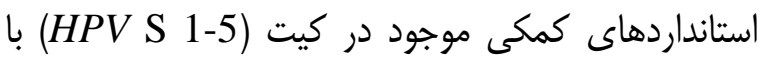
همان روش استخراج نمونه و با همان حجم، انجام شد.

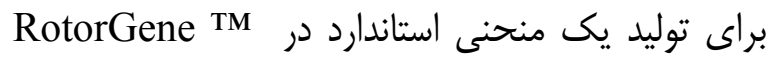


و لود ويروسى HPV با بهارگيرى كيت شركت اختصاصى در نتايج Real time PCR، منحنى ذوب براى

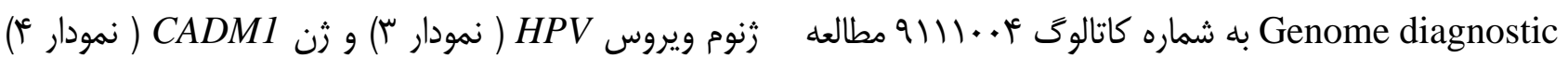

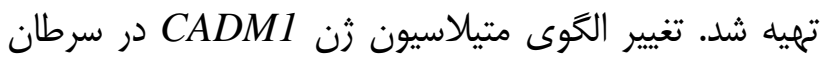
كرديد. سرويكس بيماران از روى نمونههاى بالينى قبل از درمان

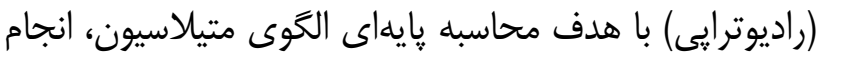

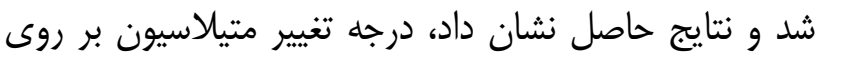

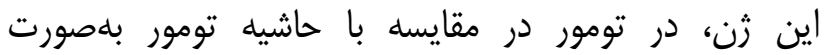

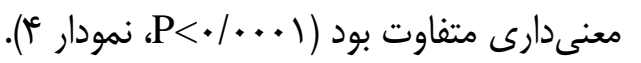

براى بررسى تغيير الخوى متيلاسيون زنوم ثن

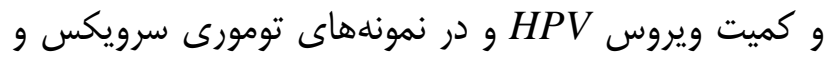

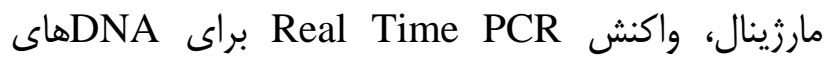
تهيهشده براى تمامى نمونهایى بافت (سرطانى و مارزينال)،

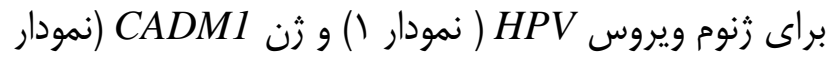

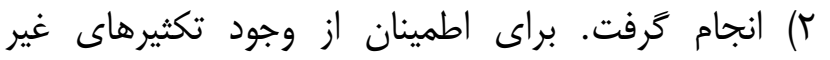

\section{Standard Curve}

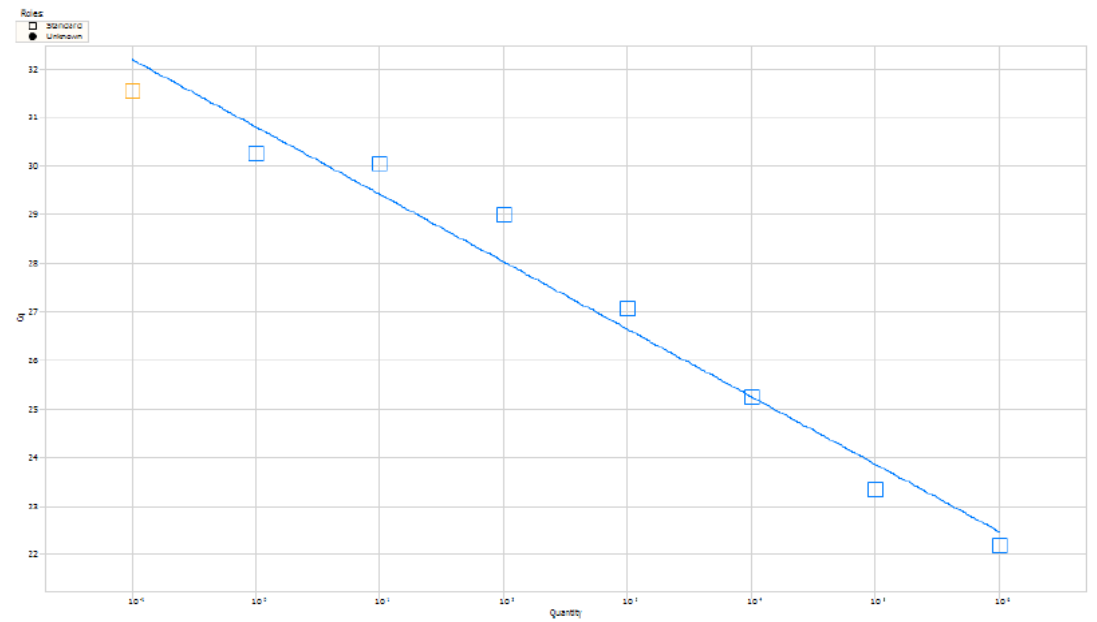

\section{Standard Curve Results}

\begin{tabular}{lllll} 
Assay Name & Color & Slope & Intercept & R2 \\
\hline Assary 1 & - & -1.38893215 & 30.81140221 & 0.96840745
\end{tabular}

نمودار ا - نمودار استاندارد نمونههاى انجامشده براى زن هدف HPV براى تعيين Real Time PCR واكنش Efficiency

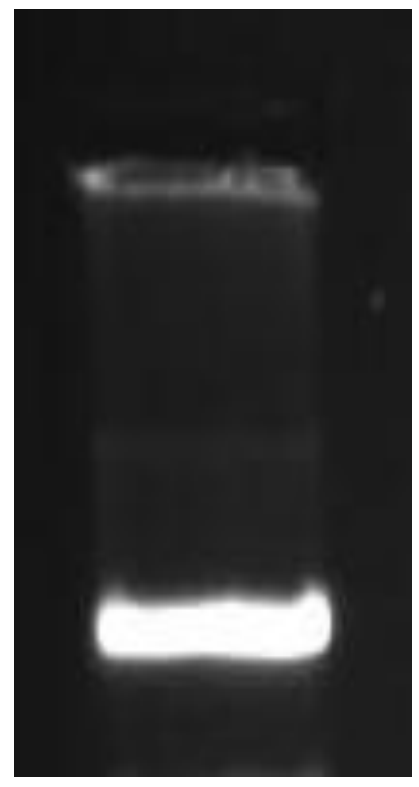

شكل ا - ظهور باند يكدست حاصل از

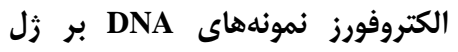
\% إخارز 


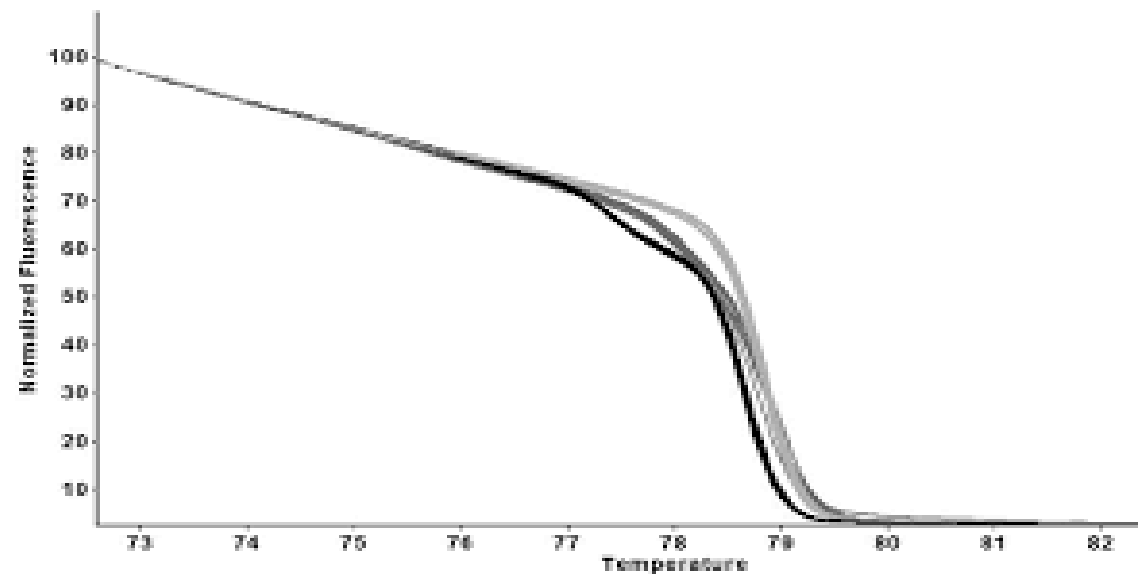

نمودار ץ- منحنى ذوب Real time PCR HRM براى زن CADM1 براى جندنمونه مثبت مبتلا به سرطانسرويكس
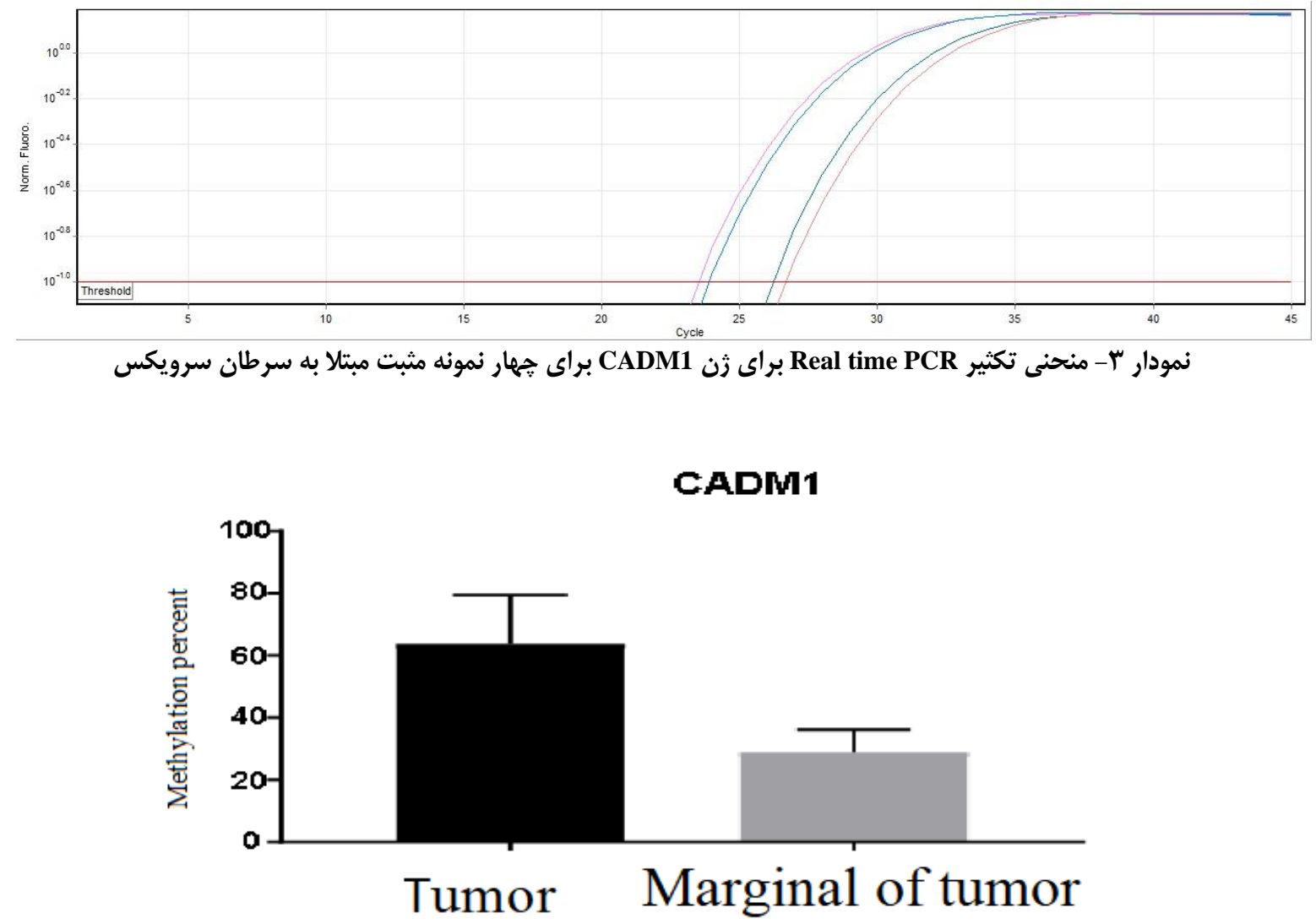

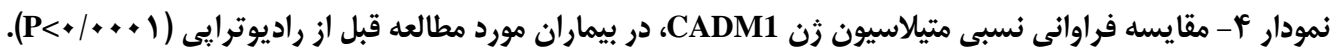


تغيير الخوى متيلاسيون زن CADM1 در سرطان تغيير الخوى متيلاسيون بر اساس درصد متيلهشدن، در

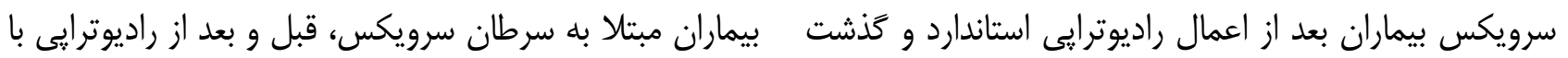

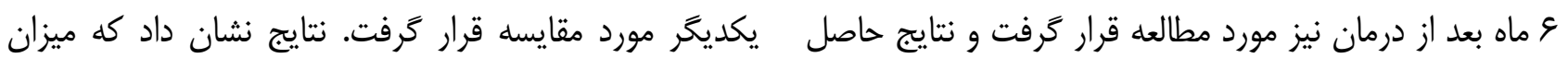

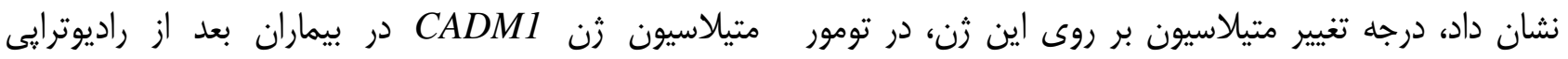

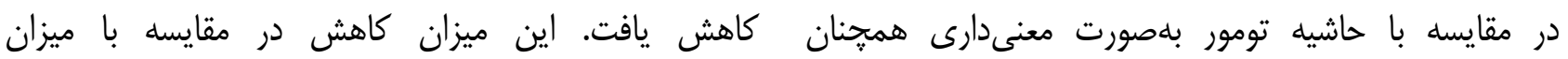

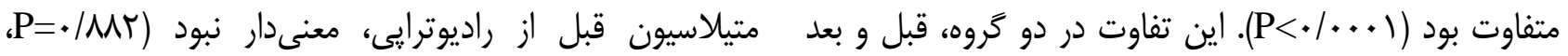

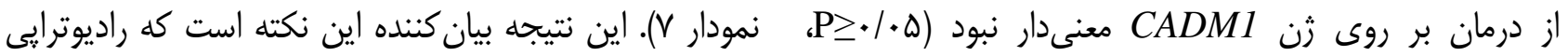

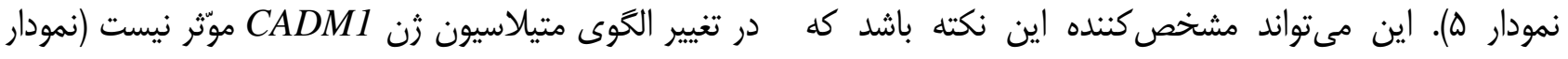

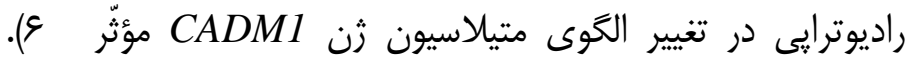

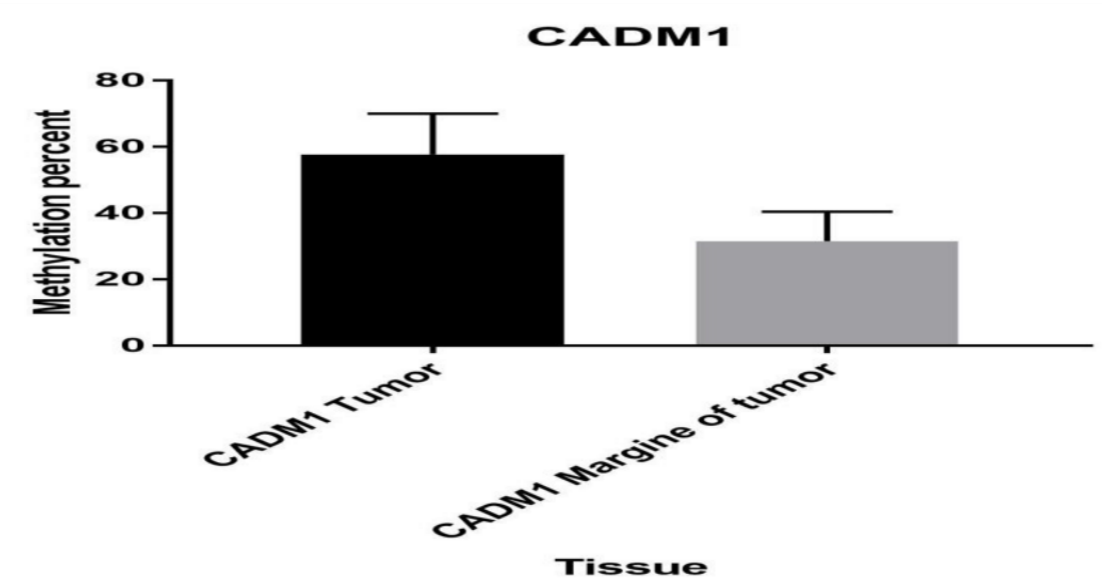

نمودار ه- مقايسه فراوانى نسبى متيلاسيون زن CADM1، در بيماران مورد مطالعه بعد از راديوترايى ( (+ + + + >).

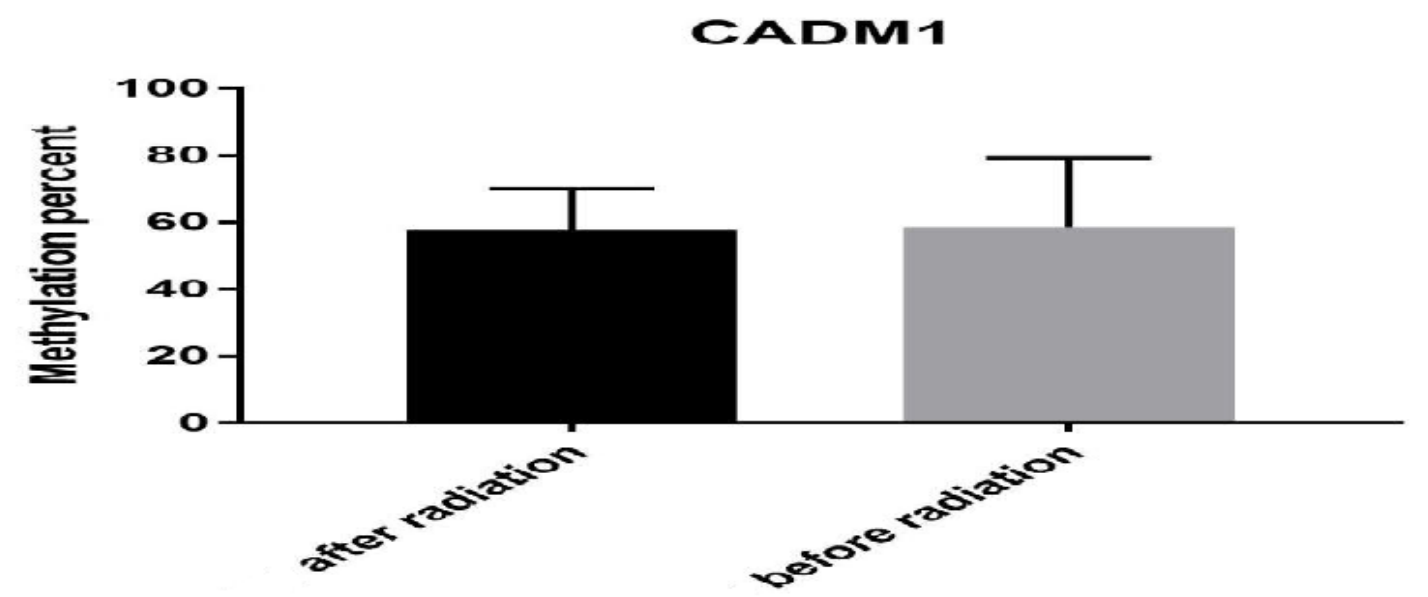

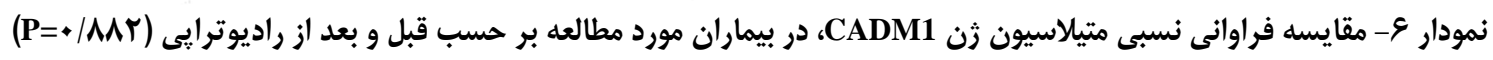




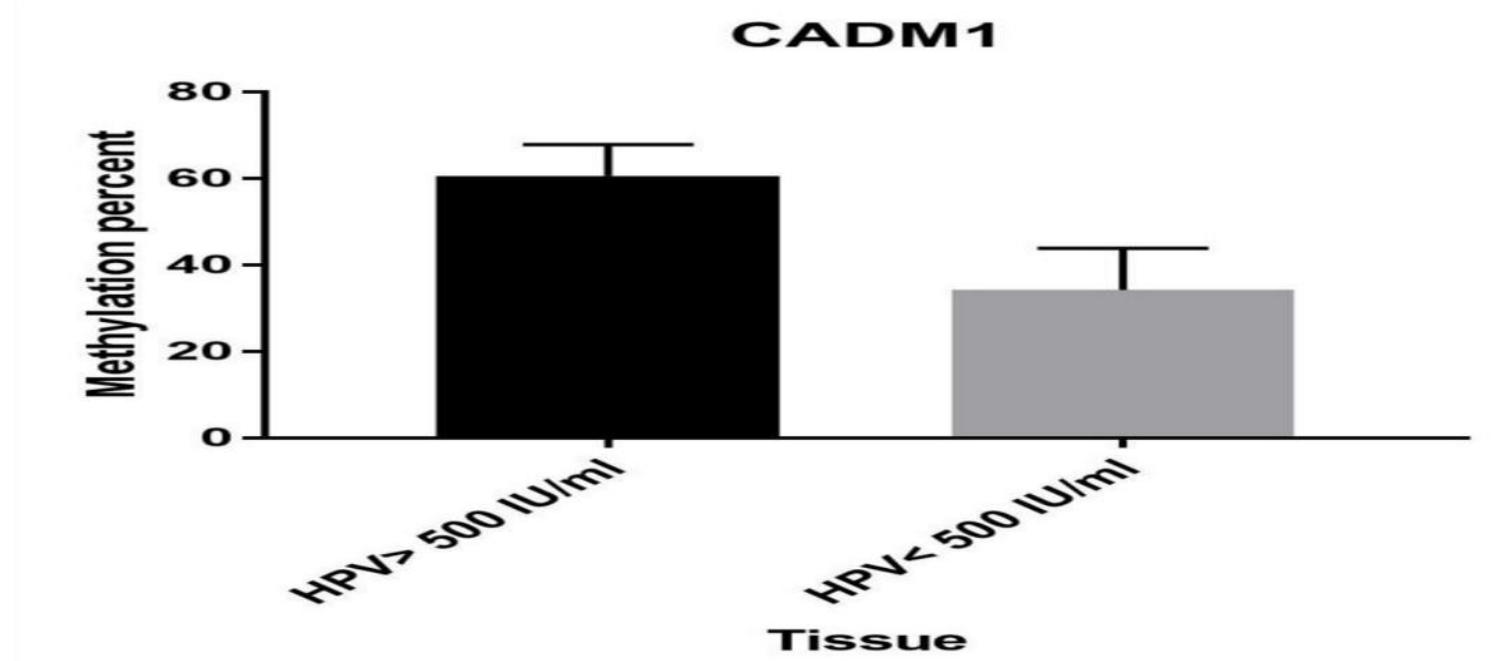

نمودار V- مقايسه فراوانى نسبى متيلهشدن زن CADM1، در نمونه بافت استخراجشده از دو تروه بيماران با تيتر HPV بيشتر و

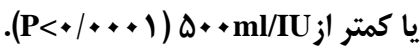

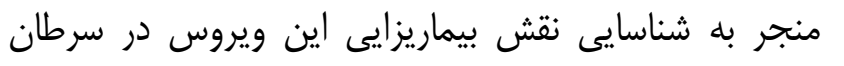

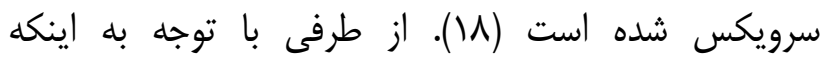

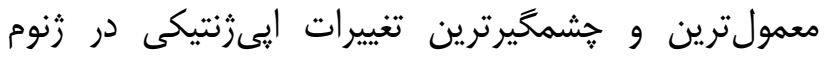

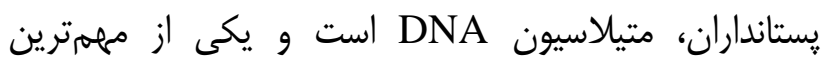

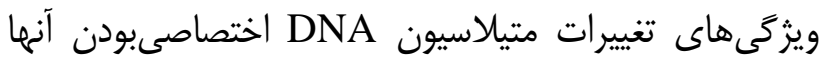
براى انواع بافت تومورى است، در اين مطالعه به برات بروسى

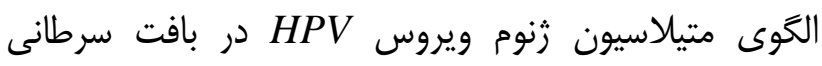

$$
\text { سرويكس يرداخته شد. }
$$

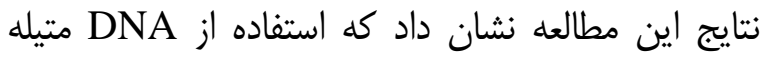

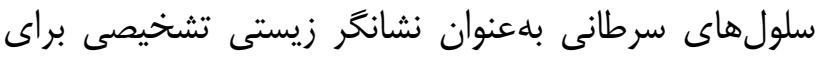

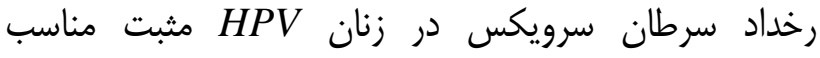

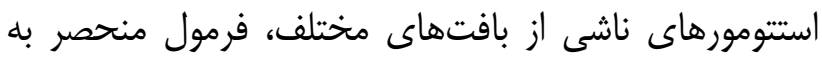

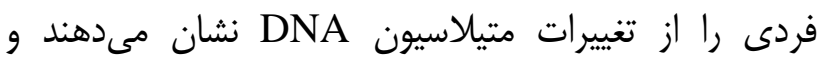

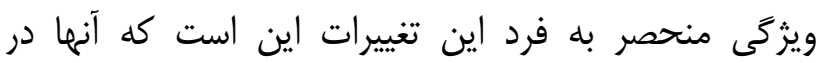

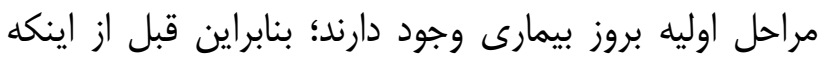
تظاهرات بالينى كارسينوزنز (سرطانزايى) شروع شوند، انجام إنيام

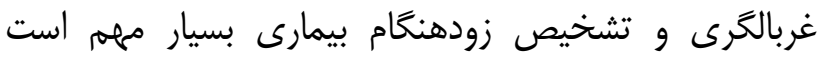

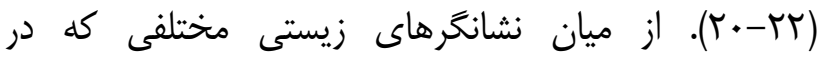
بافتهاى سرطانى دهار متيلاسيون مىشوند، نشانكرهاى
تغيير الكوى متيلاسيون زنوم HPV در سرطان سرويكس بيماران از روى نمونههاى بالينى يس از استخراج و

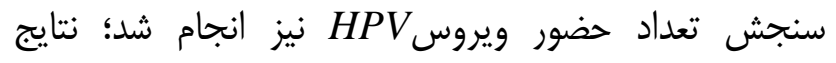

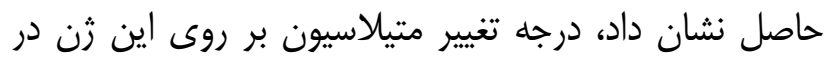

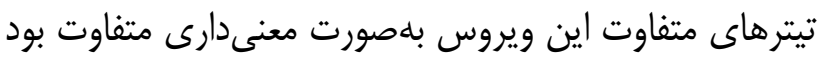

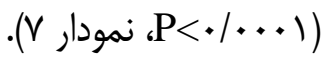
با وجود بيشرفتهاى اخير در تشخيص سرطان كردن

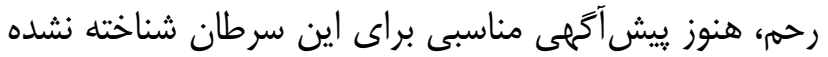

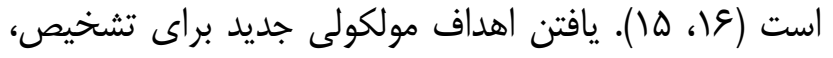

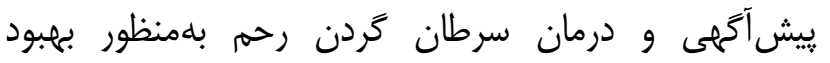

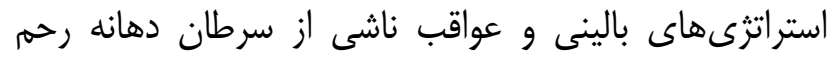

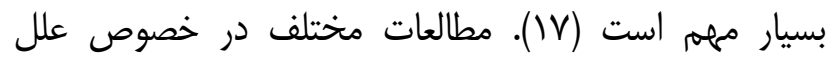
رخداد سرطان كردن رحه، علت اصلى بلهوجود آمدن اين

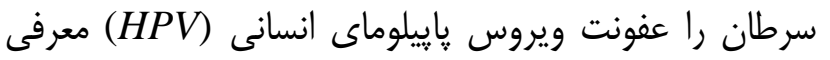

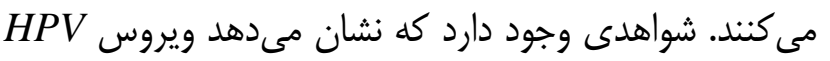

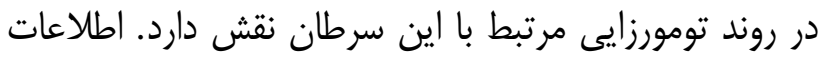
روزافزون درباره HPV و نحوه ميان كنش آن با زنوم ميزبان، 
براى غربالكرى، تشخيص و نيز روشهاى جديد درمان

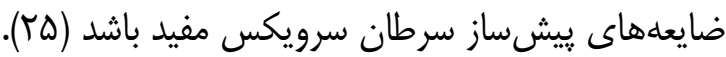

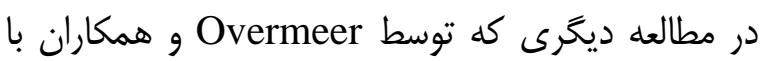
عنوان التجزيه و تحليل متيلاسيون يروموتر

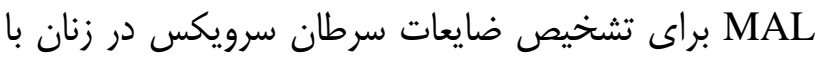
HPV بيماران HPV مثبت با تشخيص مقدار بالينى CIN3 و

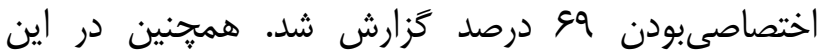

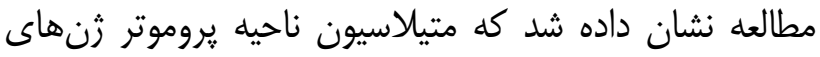

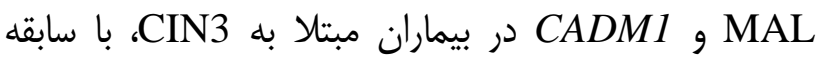
عفونت طولانى HR-HPV، افزايش مى يابد. بالاترين مقادير

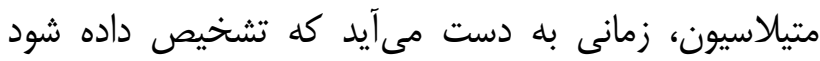

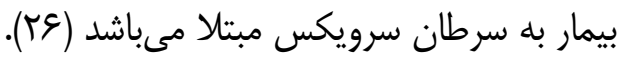

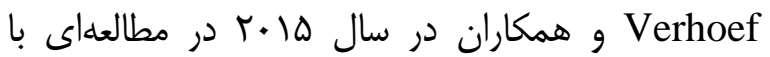
CADM1 / عنوان ابررسى متيلاسيون نشانكرهاى زيستى

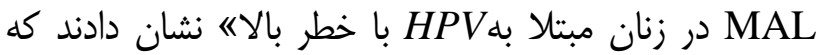

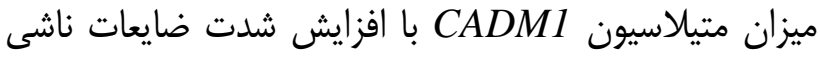
از ييشرفت سرطان سرويكس، افزايش مي يابد. آنها معتقد

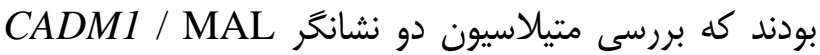

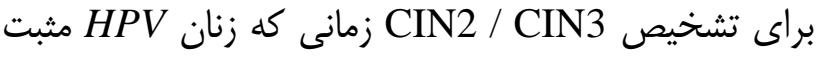

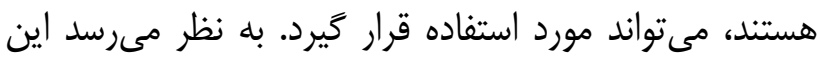

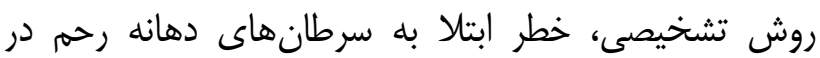
زنان HPV مثبت را كاهش دهد (TV) De Vuyst

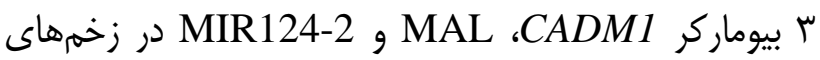

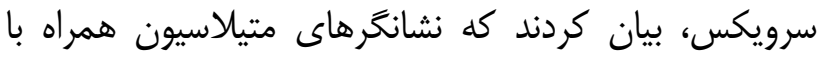

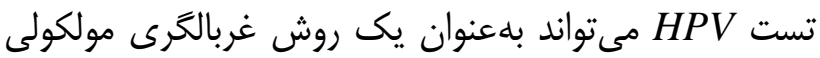
براى بسيارى از زنان hrHPV مثبت، مورد استفاده قرار كَيرد (T) (T). در مطالعه مشابه ديخرى، van Baars و همكاران نشان دادند مثبتبودن متيلاسيون CADM1 با شدت بيمارى

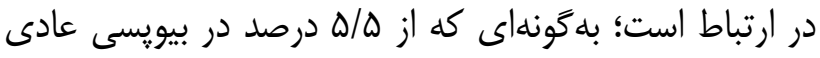

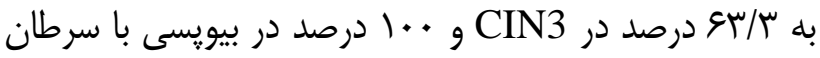

زيستى CADM1، CDH1، DAPK1، خانواده TERT g PRDM14 PAX1 ،MAL ،EPB41L3 متداولترين زنهاى متيلاسيون براى نمونههايى با كارسينوم

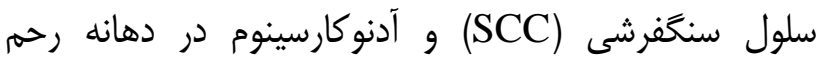

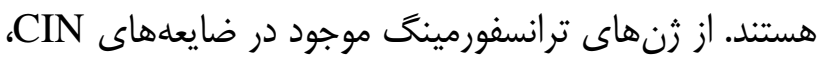
متيلاسيون زن CADM1 بالاترين ميزان را نشان مىدهد

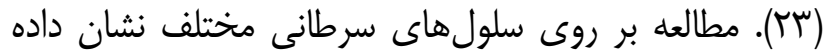

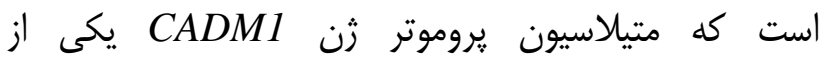
مكانيسمهاى اصلى خاموششدن بيان آن در سلولهاى

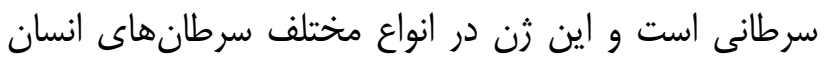

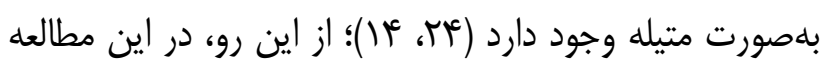

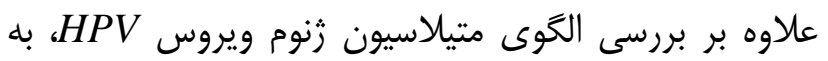
بررسى متيلاسيون زن CADM1 در بافتهاى سرطان دهان دانهان

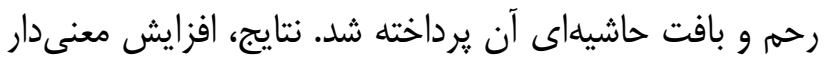
بيان CADM1 در نمونههاى سرطانى كردن رحم در مقائه با بافتهاى مجاور غير سرطانى را نشان دادي

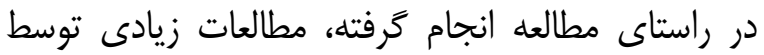
محققين ديگر انجام كرفته است. Clarke و همكاران در سال

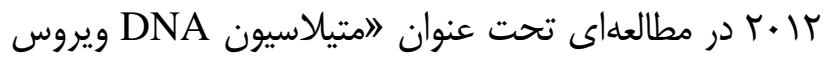

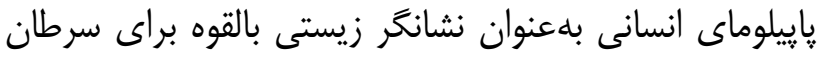

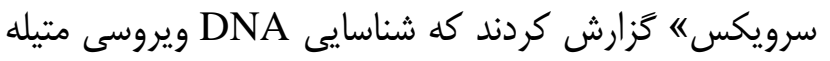
ممكن است زنان دهار نئويلازى اينترا ابى تليال سرويكس

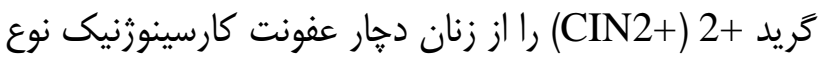

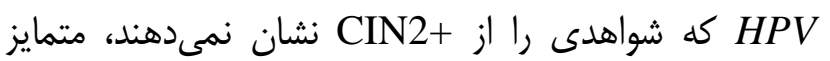
سازد (19). Mersakova با عنوان "امتيلاسيون DNA و شناسايى سرطان سرويكس

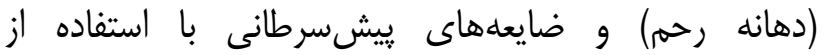

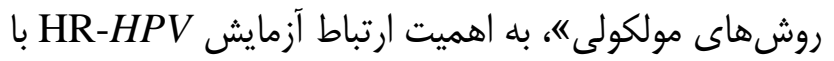

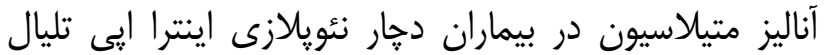

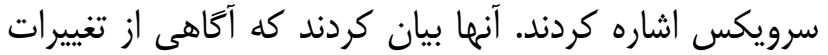
زنتيكى و إيىزنتيكى مرتبط با بروز سرطان سرويكس مى توراند 


$$
\text { سرطانها مشاهده شده است، مىتواند محققين را به يافتن }
$$

\section{تقدير و تشكر}

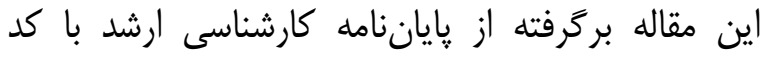

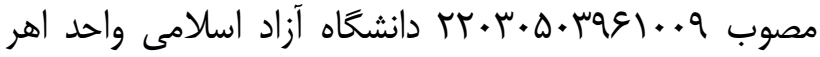

خانم اسماء سلطان عليزاده دانش آموخته رشته زنتيك در سال

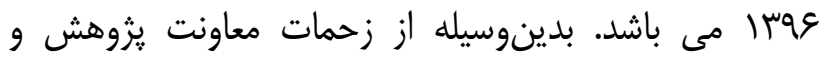

فناورى تشكر و قدردانى مى بـردد.

\section{تضاد منافع}

نويسندكان مقاله اعلام مىدارند كه هيجَّونه تضاد

منافعى در يثوهش حاضر وجود ندارد.
سرويكس افزايش مىيابد (rq).

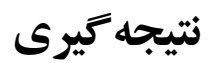

نتايج مطالعه ما نيز نشان داد كه ميزان متيلاسيون

CADMI

افزايش معنىدارى دارد؛ از طرفى، حضور ويروس HPV

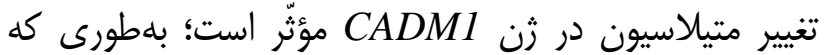
مىتوان گفتت بيماران مبتلا به سرطان سرويكس با دارن دارا بودن ويروس HPV هيبوميتلاسيون بيشترى نشان دادند. اين يافته بئه

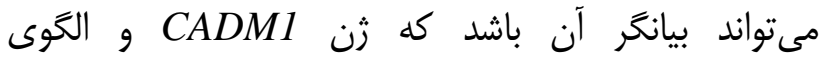
متيلاسيون اين ثن داراى كاربرد تشخيصى بوده و مىتنواند بلهنوان نشانگر تشخيصى در اين سرطان مورد استفاده قرار

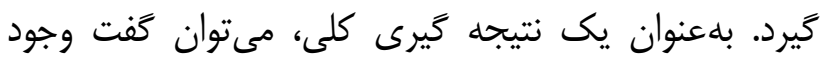

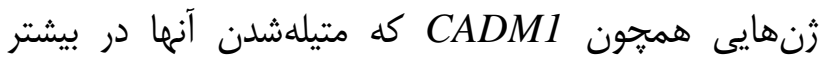

1- Koh WJ, Greer BE, Abu-Rustum NR, Apte SM, Campos SM, Cho KR, et al. Cervical cancer, version 2. 2015. J Natl Compr Canc Netw. 2015; 13(4): 395-404; quiz 404. DOI:10.6004/jnccn.2015.0055

2- Salvatici M, Achilarre MT, Sandri MT, Boveri S, Vanna Z, Landoni F. Squamous cell carcinoma antigen (SCC-Ag) during follow-up of cervical cancer patients: Role in the early diagnosis of recurrence. Gynecol Oncol. 2016; 142(1): 115-9. doi: 10.1016/j.ygyno.2016.04.029.

3- MailinhV, JimYD,Olutosin A, Awolude M, Linus C. Cervical cancer worldwide. Curr Probl Cancer. 2018; 42(5): 457-65. doi: 10.1016/j.currproblcancer.2018.06.003.

4- Chen W, Zheng R, Baade PD, Zhang S, Zeng H, Bray F, et al. Cancer statistics in China, 2015. CA Cancer J Clin. 2016; 66(2): 115-32. doi: 10.3322/caac.21338.

5-Dillner J, Sparen P, Andrae B, Strander B. [Cervical cancer has increased in Sweden in women who had a normal cell sample]. Lakartidningen. 2018;115. pii: E9FD. [Swedish]

6- Cancer Genome Atlas Research Network. Integrated genomic and molecular characterization of cervical cancer. Nature. 2017; 543: 378-84.

7- Wentzensen N, Schiffman M, Palmer T, Arbyn M. Triage of HPV positive women in cervical cancer screening. J Clin Virol. 2016; 76 Suppl 1: S49-S55. doi: 10.1016/j.jcv.2015.11.015.

8- zur Hausen H. Papillomaviruses causing cancer: evasion from host-cell control in early events in carcinogenesis. J Natl Cancer Inst. 2000; 92(9): 690-8. DOI: 10.1093/jnci/92.9.690

9- Bosch FX, Manos MM, Muñoz N, Sherman M, Jansen AM, Peto J, et al. Prevalence of human papillomavirus in cervical cancer: a worldwide perspective. International biological study on cervical cancer (IBSCC) Study Group. J Natl Cancer Inst.1995; 87(11): 796-802. DOI: 10.1093/jnci/87.11.796

10- Mulero-Navarro S, Esteller M. Epigenetic biomarkers for human cancer: the time is now. Crit Rev Oncol Hematol. 2008; 68(1): 1-11. doi: 10.1016/j.critrevonc.2008.03.001.

11- Kuramochi M, Fukuhara H, Nobukuni T, Kanbe T, Maruyama T, Ghosh HP, et al. TSLC1 is a tumor-suppressor gene in human non-small-cell lung cancer. Nat Genet. 2001; 27(4): 427-30. DOI: 10.1038/86934 
12- Ando K, Ohira M, Ozaki T, Nakagawa A, Akazawa K, Suenaga Y, et al. Expression of TSLC1, a candidate tumor suppressor gene mapped to chromosome 11q23, is downregulated in unfavorable neuroblastoma without promoter hypermethylation. Int J Cancer. 2008; 123(9): 2087-94. doi: 10.1002/ijc.23776.

13-Ito T, Shimada Y, Hashimoto Y, Kaganoi J, Kan T, Watanabe G, et al. Involvement of TSLC1 in progression of esophageal squamous cell carcinoma. Cancer Res. 2003; 63(19): 6320-6.

14- Mao X, Seidlitz E, Truant R, Hitt M, Ghosh HP. Re-expression of TSLC1 in a non-small-cell lung cancer cell line induces apoptosis and inhibits tumor growth. Oncogene. 2004; 23(33): 5632-42. DOI: 10.1038/sj.onc.1207756

15- Dasari S, Wudayagiri R, Valluru L. Cervical cancer: Biomarkers for diagnosis and treatment. Clin Chim Acta. 2015; 445: 7-11. doi: 10.1016/j.cca.2015.03.005.

16- Wang YF, Zhang S, Li XQ, Wang Y. Expression of IncRNA HULC in cervical cancer and its correlation with tumor progression and patient survival. Eur Rev Med Pharmacol Sci. 2016; 20(19): 3987-91.

17- Cao S, Liu W, Li F, Zhao W, Qin C. Decreased expression of lncRNA GAS5 predicts a poor prognosis in cervical cancer. Int J Clin Exp Pathol. 2014; 7(10): 6776-83.

18- Bosch FX, Lorincz A, Muñoz N, Meijer CJ, Shah KV. The causal relation between human papillomavirus and cervical cancer. J Clin Pathol. 2002; 55(4): 244-65. DOI: 10.1136/jcp.55.4.244

19- Clarke MA, Wentzensen N, Mirabello L, Ghosh A, Wacholder S, Harari A, et al. Human papillomavirus DNA methylation as a potential biomarker for cervical cancer. Cancer Epidemiol Biomarkers Prev. 2012; 21(12): $2125-37$. doi: 10.1158/1055-9965.EPI-12-0905.

20- Hess J. Predictive Factors for Outcome and Quality of Life in HPV-Positive and HPV-Negative HNSCC. Recent Results Cancer Res. 2017; 206: 233-42. DOI: 10.1007/978-3-319-43580-0_18

21- Gabbai D, Harlev A, Friger M, Steiner N, Sergienko R, Kreinin A, et al. Pregnancy outcomes among patients with recurrent pregnancy loss and uterine anatomic abnormalities. J Perinat Med. 2018; 46(7): 728-734. doi: 10.1515/jpm2016-0411.

22- Sheppard K, Bond S, Manek S. Diagnostic Challenge of Cervical Intraepithelial Neoplasia with Concurrent Follicular Cervicitis: Histomorphological Features and P16 Immunostaining as a Diagnostic Adjunct. Adv Cytol Pathol. 2018; 3(1): 1-3. DOI: 10.15406/acp.2018.03.00041

23- Vasiljević N, Scibior-Bentkowska D, Brentnall AR, Cuzick J, Lorincz AT. Credentialing of DNA methylation assays for human genes as diagnostic biomarkers of cervical intraepithelial neoplasia in high-risk HPV positive women. Gynecol Oncol. 2014; 132(3): 709-14. doi: 10.1016/j.ygyno.2014.02.001.

24- Fukami T, Fukuhara H, Kuramochi M, Maruyama T, Isogai K, Sakamoto M, et al. Promoter methylation of the TSLC1 gene in advanced lung tumors and various cancer cell lines. Int J Cancer. 2003; 107(1): 53-9.

25- Mersakova S, Nachajova M, Szepe P, Kasajova PS, Halasova E. DNA methylation and detection of cervical cancer and precancerous lesions using molecular methods. Tumour Biol. 2016; 37(1): 23-7. DOI: 10.1002/ijc.11348

26- Overmeer RM, Louwers JA, Meijer CJ, van Kemenade FJ, Hesselink AT, Daalmeijer NF, et al. Combined CADM1 and MAL promoter methylation analysis to detect (pre-) malignant cervical lesions in high-risk HPV-positive women. Int J Cancer. 2011; 129(9): 2218-25. doi: 10.1002/ijc.25890.

27- Verhoef VM, van Kemenade FJ, Rozendaal L, Heideman DA, Bosgraaf RP, Hesselink AT, et al. Follow-up of highrisk HPV positive women by combined cytology and bi-marker CADM1/MAL methylation analysis on cervical scrapes. Gynecol Oncol. 2015; 137(1): 55-9.

28- De Vuyst H, Franceschi S, Plummer M, Mugo NR, Sakr SR, Meijer CJ, et al. Methylation levels of CADM1, MAL, and MIR124-2 in cervical scrapes for triage of HIV-infected, high-risk HPV-positive women in Kenya. J Acquir Immune Defic Syndr. 2015; 70(3): 311-8. doi: 10.1097/QAI.0000000000000744.

29- Overmeer RM, Louwers JA, Meijer CJ, van Kemenade FJ, Hesselink AT, Daalmeijer NF, et al. Combined CADM1 and MAL promoter methylation analysis to detect (pre-)malignant cervical lesions in high-risk HPV-positive women. Int J Cancer. 2016; 138(2): 463-71. doi: 10.1002/ijc.29706. 